\title{
Income distribution and economic crises
}

\section{Bilin Neyapti}

Department of Economics, Bilkent

University, Ankara, Turkey

\section{Correspondence}

Bilin Neyapti, Department of Economics, Bilkent University, Ankara 06800,

Turkey.

Email: neyapti@bilkent.edu.tr

\section{1 | INTRODUCTION}

Income growth has been volatile around the world since the 1970s, interrupted by recessions of varying degrees of severity. ${ }^{1}$ While economics research has focused overwhelmingly on growth and efficiency especially during that period, the relationship between sustainable growth and inequality has been insufficiently explored. ${ }^{2}$

Income and wealth inequality may, to some extent, be attributed to historical and structural factors. It is also likely that these factors facilitate the formation of special interest lobbies that engage in rent-seeking activities and build extractive institutions to strengthen their socio-economic positions. ${ }^{3}$ Extractive institutions lead to allocational and distributional inefficiencies and may result in institutional sclerosis ${ }^{4}$ that eventually dominates macroeconomic outcomes. Consequently, recessions or crises are usually associated with—besides poor economic management—inefficient institutions 
that, in turn, may also be closely linked to socio-economic inequality. ${ }^{5}$ Volatility in economic growth since the 1980s may, therefore, be associated with increasing relative and absolute income inequality, ${ }^{6}$ and declining collective bargaining power of workers, commonly measured by the rate of unionization. $^{7}$

In an effort to mitigate the widespread effects of the Great Recession (GR), which originated as a financial crisis in the United States in 2008, most developed countries adopted large-scale unconventional policy measures that were mainly tentative remedies, rather than substantive reforms. ${ }^{8}$ Piketty and Saez (2013) and Piketty (2014) noted that the post-GR recovery in the United States has been experienced mainly by the top decile of the population, whose income shares have already been on an upward trend during the last four decades. ${ }^{9}$ The expanding size and influence of the financial sector in the U.S. economy, ${ }^{10}$ coupled with the decreasing lobbying power of the wage-earners, may help explain this unequal impact of GR across different income groups. ${ }^{11}$ Low preference of the political elite for progressive taxation in many countries may have also contributed to increasing income inequality around the world. ${ }^{12}$ Morlino and Quaranta (2016) and Gründler and Köllner (2017) showed, however, that democratic quality, extensive political rights, and strong middle classes in advanced economies have helped overcome the negative effects of crises. Gründler and Köllner (2017) also noted the negative effect of top income groups on redistribution. While interest group dynamics thus appear important to understanding the relationship between economic crises and income distribution, exploring their role in this relationship is beyond the scope of the current study. This study, instead, simply focuses on the association between the severity of recessions and income inequality.

The relationship between economic crises and high and persistent income and wealth inequality has recently drawn considerable research interest, in view of the widespread effects of GR. The focus in many of these studies, however, is on the relationship between financial crises and income distribution, with an emphasis on crisis prediction (see, e.g., Atkinson \& Morelli, 2010; Bazillier \& Héricourt, 2014; Bellettini \& Delbono, 2013; Bordo, 2012; Kumhof, Rancière, \& Winant, 2015; Perugini, Hölscher, \& Collie, 2013; Piketty \& Saez, 2013; Rajan, 2010; Van Treeck, 2014). Considering that not all financial crises overlap with a recession episode, however, the possible relationship between economic downturns and inequality remains to be investigated.

The novel contribution of the current study stems from the empirical analysis of the relationship between income inequality and recession severity, measured by the length of the recessionary episodes and the resulting cumulative output loss. The main hypotheses tested in this work are thus: (i) pre-recession income inequality may be related with recession severity; and (ii) post-recession income inequality may be related with the severity of foregoing economic recessions. High and persistent purchasing power gaps usually imply unequal access to markets, quality education, and healthcare. Economies with high income inequality are more likely than others to suffer from payment problems and restrained demand that hamper economic activity. While not all recession or inequality phenomena imply inefficiency, ${ }^{13}$ recessions — when coupled with high income inequality-may also be associated with increased potential for socio-political unrest that is harmful for economic prospects. These arguments form the basis of the first hypothesis.

Severe recessions are, in turn, likely to lead to organized demand for institutional reforms that target elimination of economic inefficiencies. ${ }^{14}$ Whether or not such reforms are implemented usually depends, however, on both the political power of the disadvantaged groups and the will and the ability of policy makers, which are dynamically interconnected. ${ }^{15}$ Hence, an improvement in income distribution following a recession is conditional on various structural and institutional factors, besides crises severity. This premise has guided the development of the second hypothesis tested as a part of this investigation. When inefficiencies are not overcome, inequality may persist or escalate over time, and may pave the way for further recessions. 
It must be noted that investigating the causality between recessions and income inequality is neither intended nor within the scope of the current study. A causal analysis would typically require high-frequency data, whereas the relationship examined in the present work is posited to be primarily driven by the country-specific institutional and structural factors that change slowly over time. Controlling for such exogenous factors, analyses conducted in this study contribute to the pertinent literature by focusing particularly on the associational aspect of the relationships between pre- and post-recession income inequality and recession severity, within a time-precedence framework.

In order to test these hypotheses, an original panel data set was constructed, comprising of, depending on the model specification, 62-104 countries and 89-212 country-year observations, each of which corresponds to a distinct recession episode. The empirical analysis reveals two important findings. First, after controlling for the structural, institutional, and policy indicators, higher prerecession income inequality is associated with significantly less severe recessions in middle-income countries. Second, a significant positive association between recession length and post-recession net income inequality (after deducting taxes and transfers) is present at low-to-middle levels of income and governance.

The remainder of the paper is organized as follows. Section 2 provides an overview of the related literature, along with the motivation for the current study. The data and the empirical model are presented in section 3 . The estimation results are reported in section 4 , while the paper concludes by providing some suggestions for future related work in section 5 .

\section{RELATED LITERATURE AND MOTIVATION}

According to Morelli and Atkinson (2015), the relationship between increasing income inequality and macroeconomic instability hinges on reduced domestic consumption and increasing non-performing debts. Noting that income distribution became more uneven prior to both the Great Depression (GD) and GR, Kumhof et al. (2015) developed a formal model of crisis emergence based on the relative bargaining power of the lower- and middle-income groups that face unsustainably increasing debt-toincome ratios. The authors stated that, in contrast to the post-GD period, increasing indebtedness in the post-GR period is indicative of persistent worsening of income distribution.

Similar to the theoretical literature, the focus of the empirical literature related to the present investigation has mainly been on the causal relationship between income equality and financial crises. The evidence reported in some of these studies depicts a significant relationship (see, e.g., Bellettini \& Delbono, 2013; Bordo, 2012; Perugini et al., 2013; Rajan, 2010), while no significant relationship is noted in others (see, e.g., Atkinson \& Morelli, 2010; Morelli \& Atkinson, 2015; Van Treeck, 2014). ${ }^{16}$ In many of these studies, it was noted that credit expansion, rather than worsening income distribution, has a significant association with financial crises, at least in the case of GR. Pointing to the potentially significant association between the increasing income share of the top deciles and the increasing indebtedness of the rest of the population, Piketty and Saez (2013) argued for a circular relationship between income distribution and financial fragility. ${ }^{17}$

Despite the growing academic interest in income inequality that emerged in the aftermath of the GR, the relationship between the severity of recessions and income distribution has not yet been investigated. ${ }^{18}$ This study is an attempt to close this gap by conducting an original empirical analysis based on a large and representative sample of developed and developing countries. This work differs from the prior investigations of the relationship between income inequality and financial crises in several aspects. First, not all economic downturns coincide with financial crises and the frequency of recession episodes is greater than that of financial crises. Second, financial crises and recessions may 
affect different income groups, and hence income distribution, differently. Third, even when financial crises and recessions may arise from related reasons, their duration and severity may be different.

In addition to the studies on income inequality and crises, with a focus on mainly the estimation of the likelihood of the latter, the linkage between inequality and economic growth has also been investigated extensively. Findings yielded by these studies are inconclusive regarding the sign of the association between these variables. ${ }^{19}$ Berg, Ostry, and Zettlemeyer (2012) investigated the breaks in economic growth in 140 countries, demonstrating that growth spells are positively related with income equality, in addition to other institutional and political factors. ${ }^{20}$ The current study is complementary to the work of these authors in that the factors and channels that relate to growth spells can be fundamentally different from those pertaining to recessions. While the speed of technological advancements may be the main driving force behind growth accelerations or decelerations, recessions mainly result from structural and institutional inefficiencies and policy mistakes, in addition to negative production shocks.

The present investigation differs from the study of Berg et al. (2012) in several dimensions. First, instead of the growth spells analysed by Berg et al. (2012), the endogenous variables examined here are recession severity, measured by the length and depth - which is the aggregate output loss-of a recession, and income distribution. Second, the data set employed in the current study is significantly larger than that used by Berg et al. (2012). Third, an event analysis is conducted in the present study, whereas Berg et al. (2012) estimated the proportional hazard rate.

\section{3 | THE DATA}

The empirical analyses conducted in the present study are aimed at testing the following two hypotheses: (i) pre-recession income inequality may be related with recession severity; and (ii) post-recession income inequality may be related with the severity of foregoing economic recessions. For this purpose, a panel data was constructed, which includes, depending on model specifications, 62-104 countries over the 1980-2014 period, where available. The resulting data set comprises 89-212 distinct cases in which a GDP decline was observed in consecutive years, denoted here as 'recession episodes'. Given the annual periodicity of the data set, recession is defined as the year in which an average annual decline in GDP is observed, rather than relying on the conventional description of 'two consecutive quarters of contraction in real GDP'. Hence, a recession year in the current analysis may not correspond to a recession case specified by the conventional criteria. ${ }^{21}$

The panel data set is unbalanced, with the longest time dimension (three recession episodes, or events) pertaining to Bulgaria, Czech Republic, Kyrgyz Republic, Moldova, Morocco, Netherlands, and Portugal. Based on data availability, either one or two events (recession episodes) per country were observed in the remaining sample. The sample of countries includes a roughly proportional mix of developed and developing countries. ${ }^{22}$

Recession severity is characterized by its length and depth. While length is measured as the number of consecutive years during which a contraction in real GDP is observed, depth denotes the cumulative percentage decline in real GDP during a given recession episode. For obtaining these measures, GINI indices $^{23}$ were sourced from the Standardized World Income Inequality Database (SWIID), as it has the most comprehensive coverage of comparable cross-country data. ${ }^{24}$ In the empirical analysis, the net GINI data, representing the value after deducting tax and transfers, is employed (denoted simply by GINI). Hence, GINI measures de facto income inequality. As an alternative measure, the ratio of the income share of the richest $10 \%$ to that of the poorest $10 \%$ of the population (denoted by TopBot 10) is also employed. ${ }^{25}$ Although the correlation between these two measures is high (about $80 \%$ ), the latter is 
a proxy for extreme relative inequality and may thus better reflect redistributive reform pressures. This measure, and the remaining data used in the analyses, was obtained from the World Development Indicators of the World Bank.

The macroeconomic and structural variables that serve as control variables in the model represent either 2-year averages prior to each event, ${ }^{26}$ where available, or averages over the duration of an event, depending on the model specification, as described in the following section. ${ }^{27}$ Pre- and post-recession periods are denoted by the postscripts $\_B$ and $\_$, respectively. Income distribution indicators are also measured in the post-recession period in order to test the second hypothesis. Similar to the construction of the pre-recession observations, GINI(TopBot 10)_A denote averages over a 2-year period following a recession, where data are available. In order to measure the capacity of a country to avert a recession or prevent its negative effects on income distribution, the level of GDP per capita (in $\log _{10}$, denoted by $l G D P p c$ ) is controlled for in the estimations. In addition, an index of governance ( $g o v)$ is employed to measure the level of institutional development. ${ }^{28}$ Monetary policy stance is controlled for through the CPI inflation rate (inf) and the type of exchange rate regime $(E R) .{ }^{29}$ Following the approach adopted in extant studies, the inflation data is transformed using the expression $\operatorname{Dinf}=\inf /(1+i n f)$, as this ensures that it remains in the $[0,1]$ range, preventing extreme values from potentially biasing the results. ${ }^{30}$ Finally, fiscal policy stance is controlled for by introducing the GDP shares of government spending $(G)$ and budget deficit (Def) into the model. ${ }^{31}$

Another variable of potential relevance for testing the above hypotheses is the degree of openness (denoted as open), measured by the ratio of trade to GDP. Openness may exhibit a two-fold relationship with recession severity and income distribution. On one hand, negative spillovers from trade partners may exacerbate domestic instability. On the other hand, trading with countries that have diverse economic structures may help overcome domestic downturns.

A summary of the variables used in the empirical analyses is given in Appendix 1. The first notable observation based on the appendix is that, at $7.9 \%$, the average recession depth in developing countries is much higher compared to that in developed countries (2.7\%). Second, the average recession length in both developing and developed country samples is less than 2 years (1.8 and 1.5 years, respectively). Finally, no significant differences in average income distribution were noted between pre- and post-recession periods in either sample. Nonetheless, both pre- and post-recession income inequality is much higher, on average, in developing than in developed countries. The data provided in Appendix 2 illustrates that, since the 1960s, recessions have been recurrent and increasingly more widespread around the world. It is also worth noting that the correlation between recession length and depth in developed and developing countries is 0.51 and 0.70 , respectively.

\section{4 | ESTIMATION METHOD AND THE FINDINGS}

In order to test the relationship between pre-recession income inequality and recession severity postulated in the first hypothesis, the following regression model is estimated:

$$
\text { depth(length })_{i t}=\mathrm{f}\left[\operatorname{GINI}(\operatorname{TopBot} 10) \_B_{i t}, Z_{\_} B_{i t}\right]+\eta_{i t}
$$

where the terms in round brackets indicate the use of alternative variables; that is, both recession depth and length are estimated using GINI_B and TopBot10_B as the two alternative measures of income distribution. The subscript it is a country-event identifier, where $i=1,2, \ldots, 212$ and $t=1,2,3$, respectively. The suffix ' $B$ ' stands for before the event and $Z \_B$ denotes the set of control variables that includes both the structural factors $\left\{l G D P p c_{-} B\right.$, open_B,gov_B $\}$ and the macroeconomic 
variables $\left\{G \_B, D e f \_B, \operatorname{Dinf} \_B, E R \_B\right\}$ indicating the policy stance preceding each event. Additionally, the model incorporates dummy variables in order to control for the year, as well as for the developed- and transition-country effects, whereby the latter two are denoted by $D C$ and $T E$, respectively. Given the likelihood that the relationship between prevailing income distribution and recession severity may vary with income level and institutional quality, the interactions of GINI (TopBot10)_B with $l G D P p c_{-} B$ and $g o v \_B$ are also included in the estimation. ${ }^{32}$

In order to test the second hypothesis, which states that the recession severity may be correlated with the extent of post-recession income inequality, GINI(TopBot10)_A is regressed on length and depth, while controlling for the policy and structural variables $(Z)$, in this case measured as averages for the duration of each recession episode. In order to account for the persistence of inequality over time, GINI(TopBot10)_B $B_{i t}$ is used as an additional explanatory variable. The regression model developed to test the second hypothesis is therefore given as follows:

$$
\operatorname{GINI}(\text { Top } 10) \_A_{i t}=\mathrm{h}\left[\text { depth }_{i t}, \text { length }_{i t},\left(\operatorname{GINI}(\text { TopBot } 10) \_B_{i t}, Z_{i t}\right]+\varepsilon_{i t}\right.
$$

Since the relationship between income inequality and prevailing recession severity may also be contingent on per capita income and institutional quality, this model is also estimated after including the interactive effects of $d e p t h_{i t}$ and $l_{\text {engt }} h_{i t}$ with $l G D P p c_{-} B$ and gov_B. ${ }^{33}$ The interactive terms are interpreted based on the study conducted by Brambor, Clark, and Golder (2006), as will be explained in the next section.

The two hypotheses guiding the current investigation were tested independently using the Stata software. The empirical analysis focuses on the investigation of the associations between the variables of interest, conditional on the relevant structural and institutional variables. Both models are first tested for the fixed (FE) versus random effects (RE) specifications. When the Hausman test indicates that the null hypothesis that 'the differences between the coefficients of the FE and RE specifications are not systematic' is rejected, FE should be used as the RE specification would be inconsistent. In case that the null hypothesis cannot be rejected based on the Hausman test, the Breusch-Pagan Lagrange multiplier (LM) test is used to determine whether the GLS method improves the efficiency of estimations as compared to the pooled OLS regression with robust errors. ${ }^{34}$ In sections 4.1 and 4.2 , the estimation results of Equations (1) and (2) are reported, respectively, while the results of further robustness checks are presented in section 4.3 .

\section{1 | Testing the relationship between pre-recession income inequality and recession severity}

The estimation results of Equation (1) are reported in Table 1, indicating that most of the explanatory variables are not robustly significant. ${ }^{35}$ The exception is open_B, which has a negative and statistically significant coefficient in the estimation of length, indicating that the recession-mitigating effect of openness dominates the contagion effect, on average. Both $\operatorname{DefGDP}_{-} B$ and $\operatorname{Dinf}_{-} B$ are weakly significant in the estimation of depth using TopBot10_B (last two columns). However, the coefficients of these control variables are not significant when the estimation is repeated with $G I N I \_B$, utilizng the same sample as TopBot10_B (not reported).

Although the estimated coefficients of neither GINI(TopBot10)_B nor its interactions with $l G D P p c_{\_} B$ and $g o v \_B$ are statistically significant individually, this finding cannot be generalized to all values of $l G D P p c_{-} B$ and $g o v \_B$. As the variables that are interacted with $G I N I(T o p B o t 10) \_B$ are continuous, a marginal significance analysis needs to be conducted (Brambor et al., 2006). 


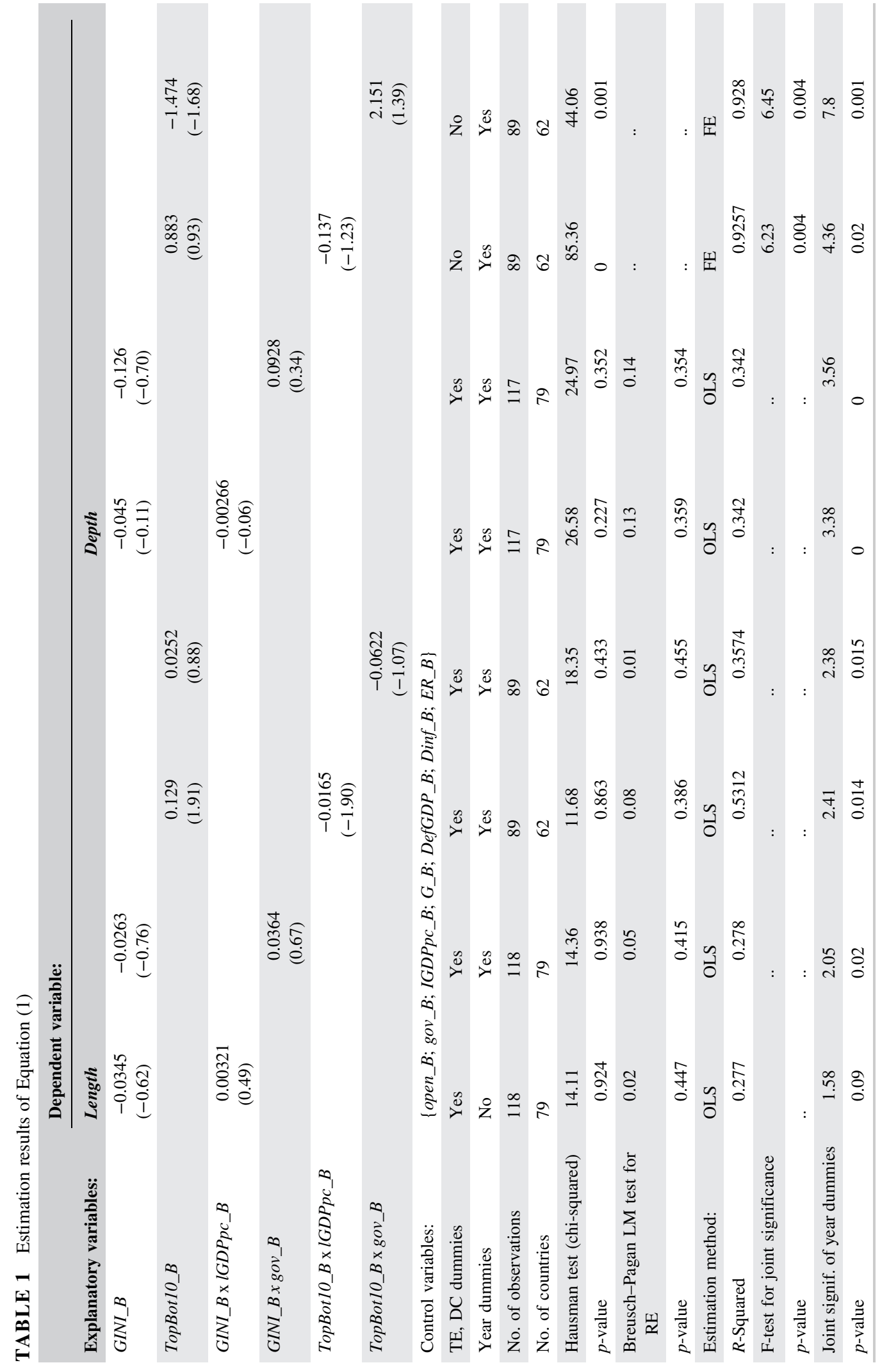



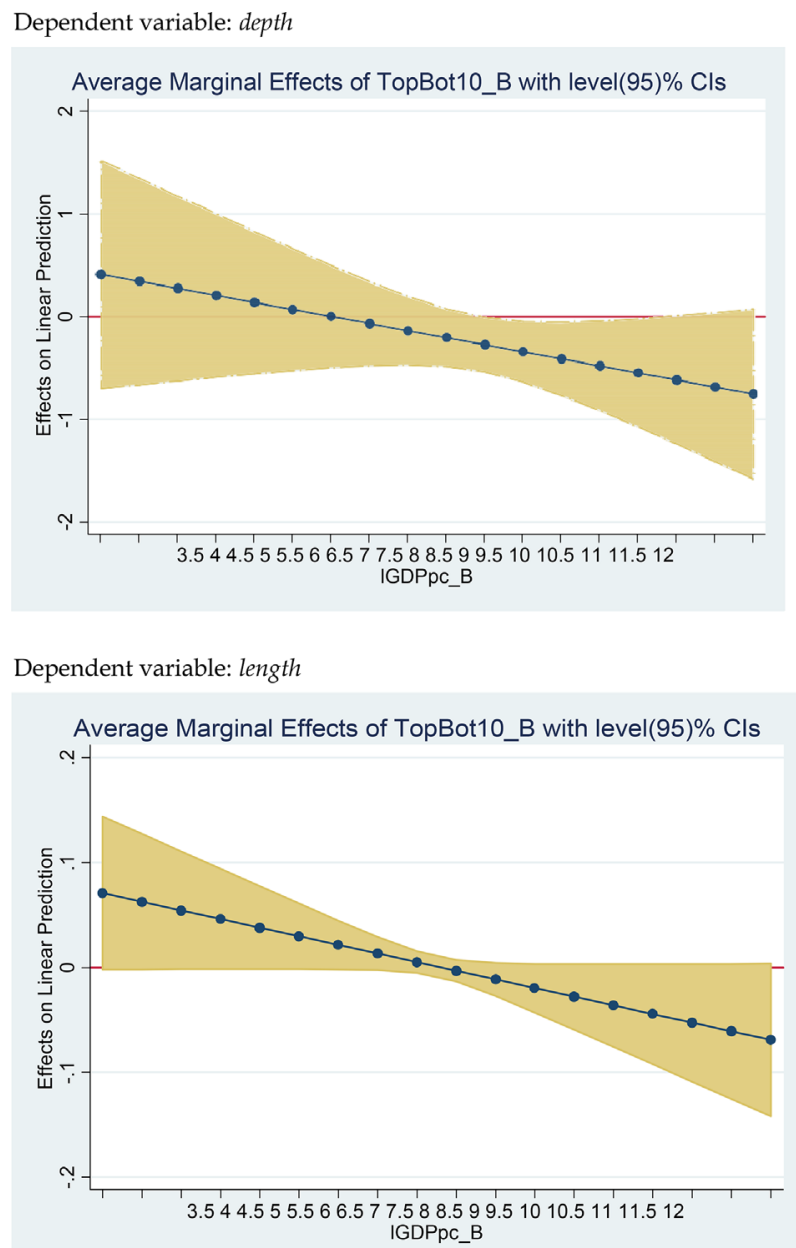

FIGURE 1 Marginal effect of TopBot10_B, conditional on $l G D P p c_{-} B$ [Colour figure can be viewed at wileyonlinelibrary.com]

In Figure 1, TopBot10_B is observed to exhibit a significant negative association with recession depth in the middle- and high-income countries. ${ }^{36}$ For the group of middle-income countries, this observation may be attributed to the dynamic nature of some of these economies that are in the process of catching up. The greater growth potential of emerging economies, notwithstanding high levels of income inequality in those countries, may help them recover from recession at a lower GDP loss compared to the rest of the sample. ${ }^{37}$ The weakly significant negative marginal effect of TopBot10_B observed at high income levels, however, can be due to high-income countries' greater capacity to pursue expansionary policies compared to those in low-income countries. Low-income economies, on the other hand, usually lack governance and economic recovery capacity; accordingly, the analysis reveals a positive relationship, which is almost significant at 95\% level of confidence, between TopBot10_B and length, while no significant relationship with depth is observed in these countries.

It is also important to elucidate the reasons behind finding no significant relationship when income inequality is measured by $G I N I \_B$, even when the estimations are performed using the same sample as that of TopBot10_B. Recalling that GINI is measured in net terms, it is possible that de facto inequality may not be sufficiently severe for mobilizing significant reform pressure towards recession 
eradication. On the other hand, because TopBot10_B measures the relative income inequality between the two extreme deciles of the population, its high values in both middle- and high-income countries may indicate stronger reform pressures that may result in policies aimed at eliminating inefficiencies. Hence, redistribution would play an important role in defining the inequality-recession relationship.

\subsection{Testing the relationship between recession severity and post-recession income distribution}

The Equation (2) estimation results are reported in Table 2. The regressions of GINI_A and TopBot10_A on depth and length include the aforementioned set of control variables $(Z)$, which are now measured as averages pertaining to each recession episode. The persistence effect, measured by the pre-crises levels of income distribution, is also controlled for in the regressions. The dummy variables controlling for year effects are excluded from these regressions, as they are not significant at conventional levels. Based on the Hausman test results, the null hypothesis that the differences between the coefficient estimates of the FE and RE specifications are systematic cannot be rejected. Hence, the FE method is chosen for the estimations of this model. This also leads to the omission of the $D C$ and $T E$ dummies.

The results reported in Table 2 reveal that that length is robustly significant in explaining the postrecession income inequality, as measured by GINI_A. The significant positive signs of GINI_B in those regressions also indicate that GINI is persistent over recessions. In the regressions of TopBot10_A, however, neither recession severity nor the persistence effect, indicated by the coefficient of TopBot10_B, is found significant. The divergent findings pertaining to these two alternative measures of inequality remain when GINI_A is estimated using the relatively smaller sample of TopBot $10 \_A .{ }^{38} \mathrm{It}$ can thus be argued that extreme relative income inequality tends to be less sustainable than the (net) GINI measure of income inequality. The observation of post-recession improvements in TopBot10 in Costa Rica, El Salvador, and Zambia—without similar improvements in GINI-is in support of this evidence (see Appendix 1).

Next, using the same method as the one adopted when estimating Equation (1), the marginal conditional correlation between recession severity and post-recession income inequality is investigated at different levels of per capita income and governance. The analysis reveals that the positive coefficient of length in the estimation of GINI_A is significant only at low and middle income levels (up to $\$ 13,360$ per capita) and governance (see Figure 2). Hence, as recessions are prolonged, (net) income inequality increases, on average, in low- and middle-income countries. By contrast, no significant correlation between recession severity and post-recession income distribution is observed for high-income countries. These observations may point to the inability of low- and middle-income countries to accommodate for the losses of low income groups that are generally impacted the most during recessions. Countries with high income and good governance, however, usually have the capacity to compensate for the impacted income groups. ${ }^{39}$ Indeed, while income per capita does not show any association with GINI, it is negatively correlated with the net GINI figures (not shown). ${ }^{40}$ In addition, the estimations do not reveal any significant association of the interactive terms with the post-recession relative inequality measure (TopBot10_A).

In sum, the empirical analyses reported in sections 4.1 and 4.2 yield three important findings. First, pre-recession relative income inequality in middle- and high-income countries is associated with less cumulative output loss during the recession than low income countries. Second, recession length is positively related to net income inequality in the low- and middle-income economies, as well as in countries with low institutional quality. Third, unlike net GINI, relative income inequality does not exhibit persistence over time. 


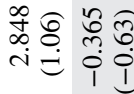

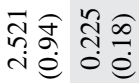

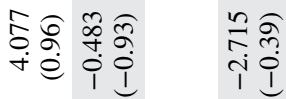

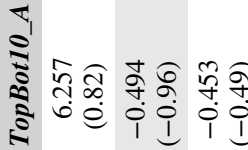

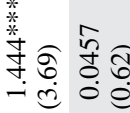

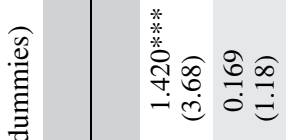

等全

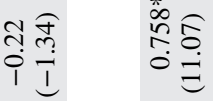

赔

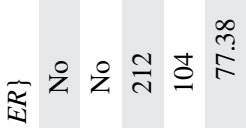

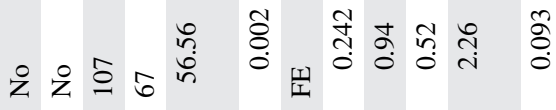

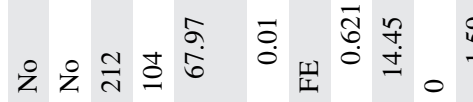

空

*

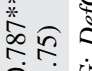

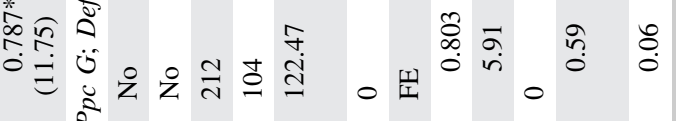
워

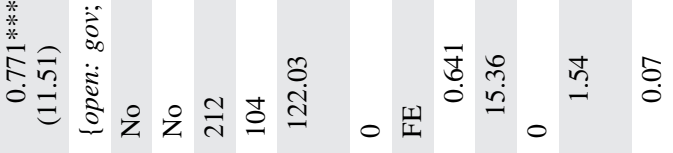

:

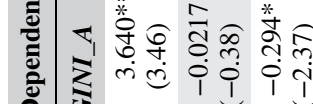

$\therefore$ ग ल

i

$\frac{\ddot{3}}{\frac{3}{\pi}}$

ง

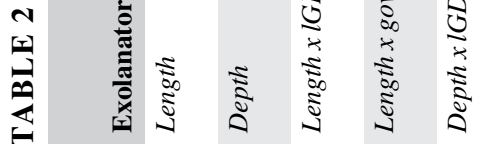

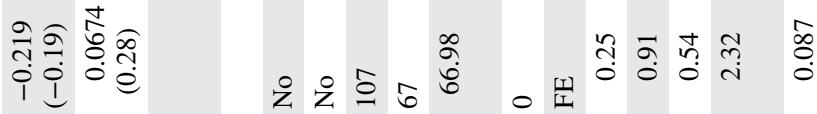

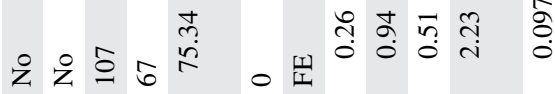

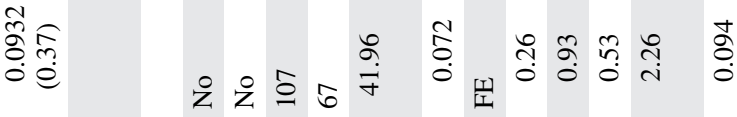

홓욜

.

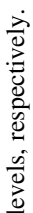

离

$\therefore$

so

需

密

胥 

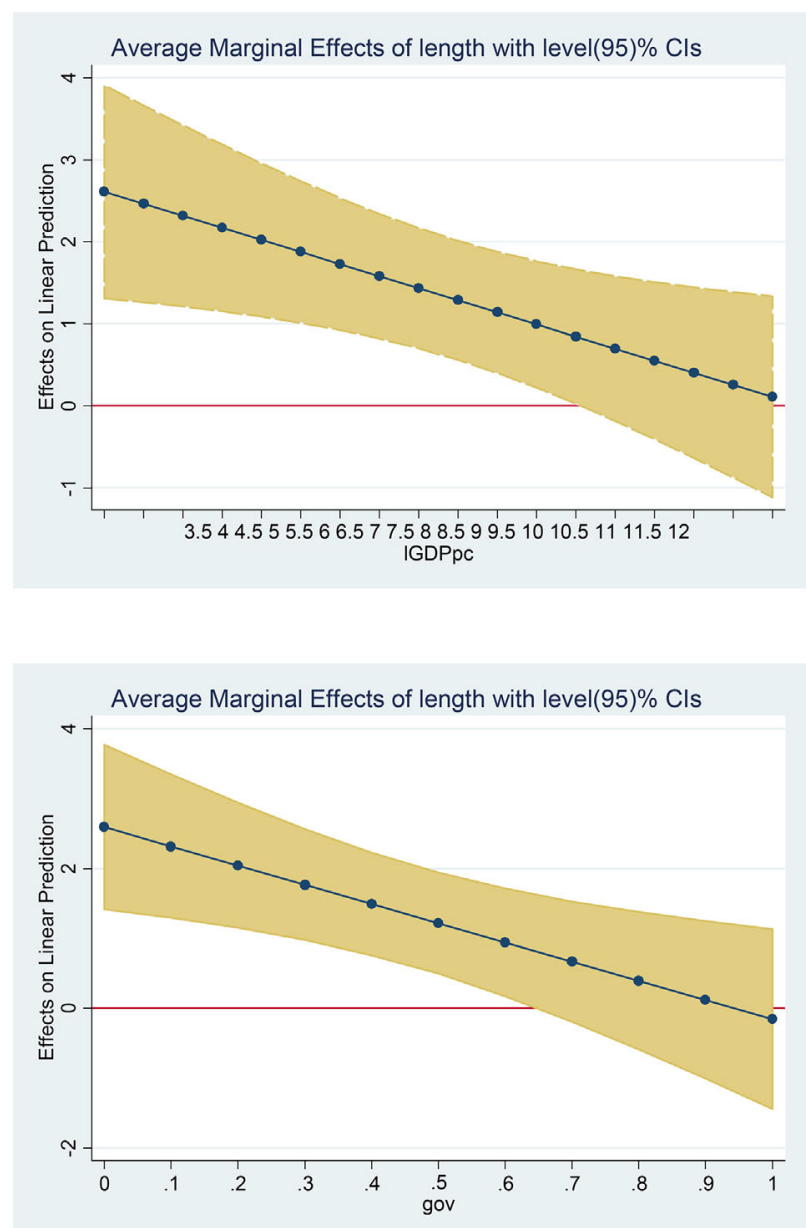

FIGURE 2 Marginal effects of length on GINI_A, conditional on $l G D P p c$ and gov [Colour figure can be viewed at wileyonlinelibrary.com]

\section{3 | Further robustness checks}

In this section, the results of additional robustness tests are reported. First, the scatter diagram in Appendix 3 shows that five countries belonging to the category of transition economies (TE) appear to be outliers. Although, in the analysis reported in the preceding sections, TE was included as a dummy variable, the robustness of the results is also evaluated by excluding these five countries from the sample. While the modestly significant results reported in Figure 1 become insignificant when the sample is restricted, the results of this robustness analysis fully support the findings reported in Figure $2 .{ }^{41}$ Hence, the second hypothesis of the present study, suggesting presence of a positive association between recession severity and post-recession income inequality, remains strongly supported by the data in case of recession length and is robust to the exclusion of outliers.

As a second robustness check, the pre- and post-recession periods are redefined as 3-instead of 2 -year windows. The variable averages are taken into account only when the data is available for at least 2 years in the identified pre- or post-recession period; hence, the number of observations in this test markedly decreases relative to that used in analyses reported in Tables 1 and $2 .^{42}$ The estimation of Equation (1) based on this revised data set shows that the significance of TopBot10_B reported in 
Figure 1 is no longer observed. Re-estimating Equation (1) using this revised data set but the 2-year windows also reveals insignificant results. ${ }^{43}$ Hence, the results reported in Table 1 and Figure 1 are not robust to sample changes. Despite a notable decline in the number of observations employed when testing the robustness of the results reported in Table 2 and Figure 2, however, the findings remain highly robust to the change in the window size. ${ }^{44}$

Next, the two models given by Equations (1) and (2) are revised to include the country size, measured in the logarithms of population, and the level of credit to the private sector, measured in percentage of GDP $(\mathrm{cr})$. The first of these variables is considered because recession recovery may be easier for larger countries, as they are likely to have more diversified economies, which helps in overcoming recessions faster. The second variable $(\mathrm{cr})$ is added, as credit expansion is cited in pertinent literature as one of the primary causes of financial crises. While investigating financial crises is not the objective of the present study, $\mathrm{cr}$ may be relevant for the analysis of the relationship between recession severity and income distribution. However, the potential effects of these two additional variables may already be captured by some of the control variables in the set $Z$. Indeed, neither of these variables is found significant and the results reported above are not significantly affected by their inclusion; hence, the regressions including these variables are not reported. Nonetheless, one interesting observation is that the negative effect of TopBot10_B on depth is associated with low levels of $c r$. In other words, when the financial market is shallow, income inequality is associated with a smaller than average output loss during recessions. ${ }^{45}$

\section{5 | CONCLUSIONS}

This study contributes to the macroeconomics literature by presenting an analysis of the relationship between income inequality and recession severity, controlling for the relevant institutional and structural factors. The empirical analysis was based on an unbalanced panel data set comprising 62-104 countries and 89-212 observations of distinct recession episodes. The severity of a recession was measured by the number of successive years in a recession and the cumulative output loss during that recession. Two hypotheses were tested as part of this investigation, namely: (i) pre-recession income inequality may be related with recession severity; and (ii) post-recession income inequality may be related with the severity of foregoing economic recessions.

The evidence presented in the preceding sections shows presence of a negative association, albeit only moderately significant, between the prevailing degree of income inequality and recession severity in middle- and high-income economies. The relationship becomes moderately positive in low-income economies, where recessions tend to be longer when associated with higher prevailing income inequality than in the rest of the sample. The relationship between recession length and post-recession income inequality in low- to middle-income countries is, however, strongly positive and robust. These findings point to the presence of a recession-inequality nexus in low-income countries.

The evidence also indicates that net income inequality in high-income countries does not exhibit any significant association with the severity of prevailing recessions. This finding can be attributed to the capacity of developed country governments to utilize various policy tools to alleviate recessions. By contrast, the low fiscal, financial, and governance capacity of low-income countries usually limit their governments' potential to recover from recessions.

As Piketty and Saez (2014) have argued, the choice of institutions and policies, besides evolving economic forces, determine the pattern of income inequality. The findings of the present study add to that discussion by highlighting the significant relationship between economic instability and inequality in low-income economies. The large global repercussions of financial and economic 
crises, coupled with differential capacity of countries to cope with those, have implications for income and wealth inequality, and possibly for political stability. The politico-economic sustainability of rising top income and wealth shares, as well as the effects of differential lobbying powers of income groups on economic stability and income equality, remain as important issues for future research. $^{46}$

\section{ACKNOWLEDGEMENTS}

I am grateful for the valuable comments of Burcin Kisacikoglu, Mine Kara, and especially two anonymous referees. I also wish to thank the participants of the seminars at Bilkent and Koc Universities and the 18th Public Economic Theory Conference in Paris, as well as Derin Aksit, who worked on the data construction for an early draft. Lastly, I owe thanks to the Editor Benn Steil, for his suggestions on the final draft.

\section{ENDNOTES}

${ }^{1}$ Global income growth has been negative in about half of the 1970-2000 period, as well as in 2009 (source: World Economic Indicators, the World Bank).

${ }^{2}$ Hsu (2016) explains why inequality is inefficient.

${ }^{3}$ See Acemoglu and Robinson (2012).

${ }^{4}$ The term, coined by Olson (1982), refers to problems related to overdue institutional reforms.

${ }^{5}$ Real, financial, and institutional factors are shown to have significant effects on the likelihood of crises (Allen \& Gale, 2007).

${ }^{6}$ See, for example, Liberati (2015), Piketty (2014), Carr and Jayadev (2015), and Goda (2016).

${ }^{7}$ Trade Unions and Collective Bargaining, OECD Statistics.

${ }^{8}$ Heathcote, Perri, and Violante (2010), Meyer and Sullivan (2012), and Thompson and Smeeding (2013) all point to the rising wage and income inequality in the United States after the GR, despite redistributive fiscal policy and increased access to financial markets. In contrast to studies showing a negative relationship between financial liberalization and income inequality (see, e.g., Beck, Levine, \& Levkov, 2010; Bumann \& Lensink, 2016), de Haan and Sturm (2017) and de Haan, Pleninger, and Sturm (2018) argue that financial liberalization worsens income inequality, in particular when the financial system is highly developed.

${ }^{9}$ See https://inequality.org/facts/income-inequality/

${ }^{10}$ See, for example, Greenwood and Scharfstein (2013).

${ }^{11}$ Union membership in the United States has declined since the 1950s, reaching $11.5 \%$ in 2016, as compared to the OECD average of $32 \%$ (https://inequality.org/facts/income-inequality/ and OECD statistics).

${ }^{12}$ See, for example, An and Ye (2017) for the case of China.

${ }^{13}$ Recessions may also be associated with creative destruction, and inequality may reflect differential ability or effort.

${ }^{14}$ Gourevitch (1986) and Gasiorowski (1995), for example, note the regime and systemic changes following major crises. Dincer and Neyapti (2008) note the reforms after banking crises.

${ }^{15}$ See, for example, Alesina and Perotti (1996) and Acemoglu and Robinson (2012).

${ }^{16}$ Van Treeck (2014) argues that, while the relative income hypothesis may explain the increasing credit demand in the United States, the GR can be explained by credit expansion alone, rather than worsening income distribution.

${ }^{17}$ See also Claessens and Perotti (2007) and Bazillier and Héricourt (2014).

${ }^{18}$ Datt and Hoogeveen (2003) and Lustig (1990), however, show that economic crises increase the depth and severity of poverty.

${ }^{19}$ See, for example, Persson and Tabellini (1994), Benabou (1996), Aghion, Caroli, and García-Peñalosa (1999), Forbes (2000), Scully (2002), and Campano and Salvatore (2006). In a mega-study, de Dominicis, Florax, and de Groot (2008) 
discuss four channels that link inequality and growth negatively: distortionary endogenous fiscal policy; credit constraints for the poor and low marginal return to investment to rich; socio-political instability; and high fertility differentials.

${ }^{20}$ The authors estimate the hazard rate for the growth spells, identified as the duration of growth accelerations.

${ }^{21}$ An annual recession may be observed when the real GDP contracts in two non-consecutive quarters, or even in only one quarter, if it dominates the annual average.

22 See Appendix 1.

23 de Dominicis et al. (2008) argue that, as various measures of inequality are highly correlated, GINI is preferred for its highest level of comparability across studies.

${ }^{24}$ According to Solt (2016), net-income inequality data is the most suitable for this type of analysis. The data set is available online at: http://fsolt.org/swiid/.

${ }^{25}$ Data for the top and bottom 1 and 5 percentiles of income shares is insufficient for conducting such analysis.

${ }^{26}$ Alternatively, 3-year averages are also considered to assess the robustness of the results.

${ }^{27}$ When the data in a relevant pre- and/or post-recession period exists for only 1 year, that year is also treated as an observation.

${ }^{28}$ After normalizing each of the highly correlated six Worldwide Governance Indicators (control of corruption, government effectiveness, regulatory quality, rule of law, political stability, and voice and accountability) to the [0,1] interval, their unweighted averages are used to construct a single index of governance (gov). (Source: The World Bank www.govindicators.org)

29 The data on exchange rate regimes were obtained from the Reinhart and Rogoff data set (http://www.carmenreinhart. com/data/browse-by-topic/topics/11/), based on the IMF classification for 1970-2010. The classification ranges from 1 to 6 , with higher values denoting greater flexibility.

${ }^{30}$ See, for example, Cukierman, Webb, and Neyapti (1992).

31 The analyses with the ratio of total debt to GDP, as an alternative measure of fiscal stance, are not reported due to a significant reduction in the sample size.

${ }^{32}$ Measures of religious and ethnolinguistic fractionalization and polarization could also be employed to proxy divergent interests that may affect redistribution. However, empirical findings pertaining to the relationship between ethnolinguistic fractionalization and redistribution are inconclusive; see, for example, Barro (2000), Alesina, Devleeschauwer, Easterly, Kurlat, and Wacziarg (2003), and Desmet, Ortuño-Ortín, and Wacziarg (2009). Sturm and de Haan (2015) show that this relationship is conditional on economic freedom. The current empirical analysis does not account for these variables, as they reduce the sample size to 59 countries.

${ }^{33}$ Although correlations change with the subsamples that vary with each model specification, the unrestricted sample correlations of $l G D P p c \_B$ with length and depth are $(0.03 ;-0.11)$ for the sample of developed countries, and $(0.24$; 0.46) for the sample of developing countries (based on 33 and 323 observations, respectively). I acknowledge the referee who pointed out that the negative correlation between income and depth in the developed-country sample is expected due to the already low growth rates in developed countries.

34 The null hypothesis of the LM test is that the random effects are not significantly different from zero and its rejection indicates that OLS specification is inappropriate.

${ }^{35}$ A control variable is considered to be robustly significant if it is significant across the samples and alternative income inequality measures. Since TopBot10_B has fewer observations, the estimation with GINI_B is repeated using the same sample as TopBot10_B; the only control variable that remains statistically significant for both samples and income distribution measures is open_B.

36 The significant effect is observed for GDP per capita of above $\$ 5,000$ ( $\left.l G D P p c_{-} B>8.5\right)$.

${ }^{37}$ Altug, Emin, and Neyapti (2012) argue that business cycle characteristics of developing and emerging economies are largely variable.

${ }^{38}$ The significance of length and GINI_B remains robust when the sample is restricted to that of TopBot10_A. These estimations are available from the author upon request.

${ }^{39}$ Based on the sample utilized in the present analysis, the average improvement in the net GINI figures-comparing the pre- and post-recession periods - is approximately 2 and 0.5 for developed and developing countries, respectively. 
40 The related figures are available from the author upon request.

41 The sample sizes decline by 30 and 37 observations in the estimation of Equations (1) and (2), respectively.

${ }^{42}$ The data set for the estimation of Equation (1) using GINI_B and TopBot10_B is reduced by 12 and 15 observations, respectively. In the estimation of Equation (2), the respective decreases are much higher, at 92 and 35 observations, leaving 107 and 72 observations for the estimations of GINI_A and TopBot10_A, respectively.

${ }^{43}$ GINI_B has a negative significant effect on depth at middle income and modest governance levels, similar to the findings pertaining to TopBot10_B depicted in Figure 1.

${ }^{44}$ Robustness tests results are available upon request.

45 This finding supports those reported by de Haan and Sturm (2017), who argue that financial development, commonly measured through $\mathrm{cr}$, increases the inequality-raising effect of financial liberalization.

${ }^{46}$ Comprehensive panel data on the top 1 and 5\% income shares, as well as relative poverty and wealth distribution, would be extremely valuable for studies of this kind.

\section{ORCID}

Bilin Neyapti iD http://orcid.org/0000-0002-1819-7804

\section{REFERENCES}

Acemoglu, D., \& Robinson, J. A. (2012). Why nations fail: The origins of power, prosperity and poverty. New York, NY: Crown.

Aghion, P., Caroli, E., \& García-Peñalosa, C. (1999). Inequality and economic growth: The perspective of the new growth theories. Journal of Economic Literature, 37(4), 1615-1660.

Alesina, A., Devleeschauwer, A., Easterly, W., Kurlat, S., \& Wacziarg, R. (2003). Fractionalization. Journal of Economic Growth, 8(2), 155-194.

Alesina, A., \& Perotti, R. (1996). Income distribution, political instability, and investment. European Economic Review, 40(6), 1203-1228.

Allen, F., \& Gale, D. (2007). Understanding financial crises. Oxford, UK: Oxford University Press.

Altug, S., Emin, M., \& Neyapti, B. (2012). Institutions and business cycles. International Finance, 15(3), 347-366.

An, W., \& Ye, M. (2017). Mind the gap: Disparity in redistributive preference between political elites and the public in China. European Journal of Political Economy, 50, 75-91.

Atkinson, A. B., \& Morelli, S. (2010). Inequality and banking crises: A first look. Report for the International Labor Foundation, ILO. Available at: https://www.tony-atkinson.com/researchpapers/Atkinson_and_Morelli_-_Inequality_ and_Banking_Crises_-_A_First_Look.pdf

Barro, R. J. (2000). Inequality and growth in a panel of countries. Journal of Economic Growth, 5(1), 5-32.

Bazillier, R., \& Héricourt, J. (2014). The circular relationship between inequality, leverage, and financial crises: Intertwined mechanisms and competing evidence (CEPII Working Papers, No. 22).

Beck, T., Levine, R., \& Levkov, A. (2010). Big bad banks? The winners and losers from bank deregulation in the United States. The Journal of Finance, 65(5), 1637-1667.

Bellettini, G., \& Delbono, F. (2013). Persistence of high income inequality and banking crises: 1980-2010 (CESIFO Working Papers, No. 4293).

Benabou, R. (1996). Inequality and growth (NBER Working Papers, No. 5658).

Berg, A., Ostry, J. D., \& Zettlemeyer, J. (2012). What makes growth sustained? Journal of Development Economics, 98(2), 149-166.

Bordo, M. D. (2012). Does inequality lead to financial crisis? (NBER Working Papers, No. 17896).

Brambor, T., Clark, W., \& Golder, M. (2006). Understanding interaction models: Improving empirical analyses. Political Analysis, 14(1), 63-82.

Bumann, S., \& Lensink, R. (2016). Capital account liberalization and income inequality. Journal of International Money and Finance, 61, 143-162.

Campano, F., \& Salvatore, D. (2006). Income distribution. Oxford, UK: Oxford University Press. 
Carr, M. D., \& Jayadev, A. (2015). Relative income and indebtedness: Evidence from panel data. Review of Income and Wealth, 61(4), 759-772.

Claessens, S., \& Perotti, E. (2007). Finance and inequality: Channels and evidence. Journal of Comparative Economics, 35(4), 748-773.

Cukierman, A., Webb, S., \& Neyapti, B. (1992). Measuring the independence of central banks and its policy outcomes. World Bank Economic Review, 6(3), 353-398.

Datt, G., \& Hoogeveen, H. (2003). El Niño or el peso? Crisis, poverty and income distribution in the Philippines. World Development, 31(7), 1103-1124.

de Dominicis, L., Florax, R. J. G. M., \& de Groot, H. L. F. (2008). Meta-analysis on the relationship between income inequality and economic growth. Scottish Journal of Political Economy, 55(5), 654-682.

de Haan, J., Pleninger, R., \& Sturm, J.-E. (2018). Does the impact of financial liberalization on income inequality depend on financial development? Some new evidence. Applied Economics Letters, 25, 313-316.

de Haan, J., \& Sturm, J. E. (2017). Finance and income inequality: A review and new evidence. European Journal of Political Economy, 50, 171-195.

Desmet, K., Ortuño-Ortín, I., \& Wacziarg, R. (2009). Linguistic diversity and redistribution. Journal of the European Economic Association, 7(6), 1291-1318.

Dincer, N., \& Neyapti, B. (2008). What determines the legal quality of bank regulation and supervision? Contemporary Economic Policy, 26(4), 607-622.

Forbes, K. J. (2000). A reassessment of the relationship between inequality and growth. American Economic Review, 90(4), 869-887.

Gasiorowski, M. J. (1995). Economic crisis and political regime change: An event history analysis. American Political Science Review, 89(4), 882-897.

Goda, T. (2016). Global trends in relative and absolute inequality. Ecos de Economía, 20(42), 46-69.

Gourevitch, P. A. (1986). Politics in hard times: Comparative responses to international economic crises. Ithaca, NY: Cornell University Press.

Greenwood, R., \& Scharfstein, D. (2013). The growth of finance. Journal of Economic Perspectives, 27(2), 3-28.

Gründler, K., \& Köllner, S. (2017). Determinants of governmental redistribution: Income distribution, development levels, and the role of perceptions. Journal of Comparative Economics, 45(4), 930-962.

Heathcote, J., Perri, F., \& Violante, G. (2010). Unequal we stand: An empirical analysis of economic inequality in the US, 1967-2006. Review of Economic Dynamics, 13(1), 15-51.

Hsu, S.-L. (2016). Inefficient inequality. Indiana Journal of Law and Social Equality, 5(1), 1-46.

Kumhof, M., Rancière, R., \& Winant, P. (2015). Inequality, leverage and crises: The case of endogenous default. American Economic Review, 105(3), 1217-1245.

Liberati, P. (2015). The world distribution of income and its inequality, 1970-2009. The Review of Income and Wealth, 61(2), 248-273.

Lustig, N. (1990). Economic crisis, adjustment and living standards in Mexico, 1982-85. World Development, 18(10), 1325-1342.

Meyer, B. D., \& Sullivan, J. X. (2012). Consumption, income inequality and the great recession. American Economic Review, 103(3), 178-183.

Morelli, S., \& Atkinson, A. B. (2015). Inequality and crises revisited. Economia Politica, 32(1), 31-51.

Morlino, L., \& Quaranta, M. (2016). What is the impact of the economic crisis on democracy? Evidence from Europe. International Political Science Review, 37(5), 618-633.

Olson, M (1982). The rise and decline of nations. New Haven, CT: Yale University Press.

Persson, T., \& Tabellini, G. (1994). Is inequality harmful for growth? American Economic Review, 84(3), $600-621$.

Perugini, C., Hölscher, J., \& Collie, S. (2013). Inequality, credit expansion and financial crises (MPRA Papers, No. 51336).

Piketty, T. (2014). Capital in the twenty first century. Cambridge, MA: Harvard University Press.

Piketty, T., \& Saez, E. (2013). Top incomes and the great recession: Recent evolutions and policy implication. IMF Economic Review, 61(3), 456-478.

Rajan, R. (2010). Fault lines: How hidden fractures still threaten the world economy. Princeton, NJ: Princeton University Press. Scully, G. W. (2002). Economic freedom, government policy and the trade-off between equity and economic growth. Public Choice, 113(1-2), 77-96. 
Solt, F. (2016). The standardized world income inequality database. Social Science Quarterly, 97(5), $1267-1281$.

Sturm, J.-E., \& de Haan, J. (2015). Income inequality, capitalism, and ethno-linguistic fractionalization. American Economic Review, 105(5), 593-597.

Thompson, J., \& Smeeding, T. (2013). Inequality and poverty in the United States: The aftermath of the great recession (Finance and Economics Discussion Series of Federal Reserve Board of Governors, No. 51).

Van Treeck, T. (2014). Did inequality cause the U.S. financial crisis? Journal of Economic Surveys, 28(3), 421-448.

How to cite this article: Neyapti B. Income distribution and economic crises. International Finance. 2018;21:273-296. https://doi.org/10.1111/infi.12135

\section{APPENDIX 1}

Summary of the data set (data are reported as averages over time; before and after refer to 2 years before and after recession episodes, respectively; Depth and Length refer to recession severity; GINI and Top10/Bottom10 are measures of inequality. Data sources are WDI of the World Bank and SWIID).

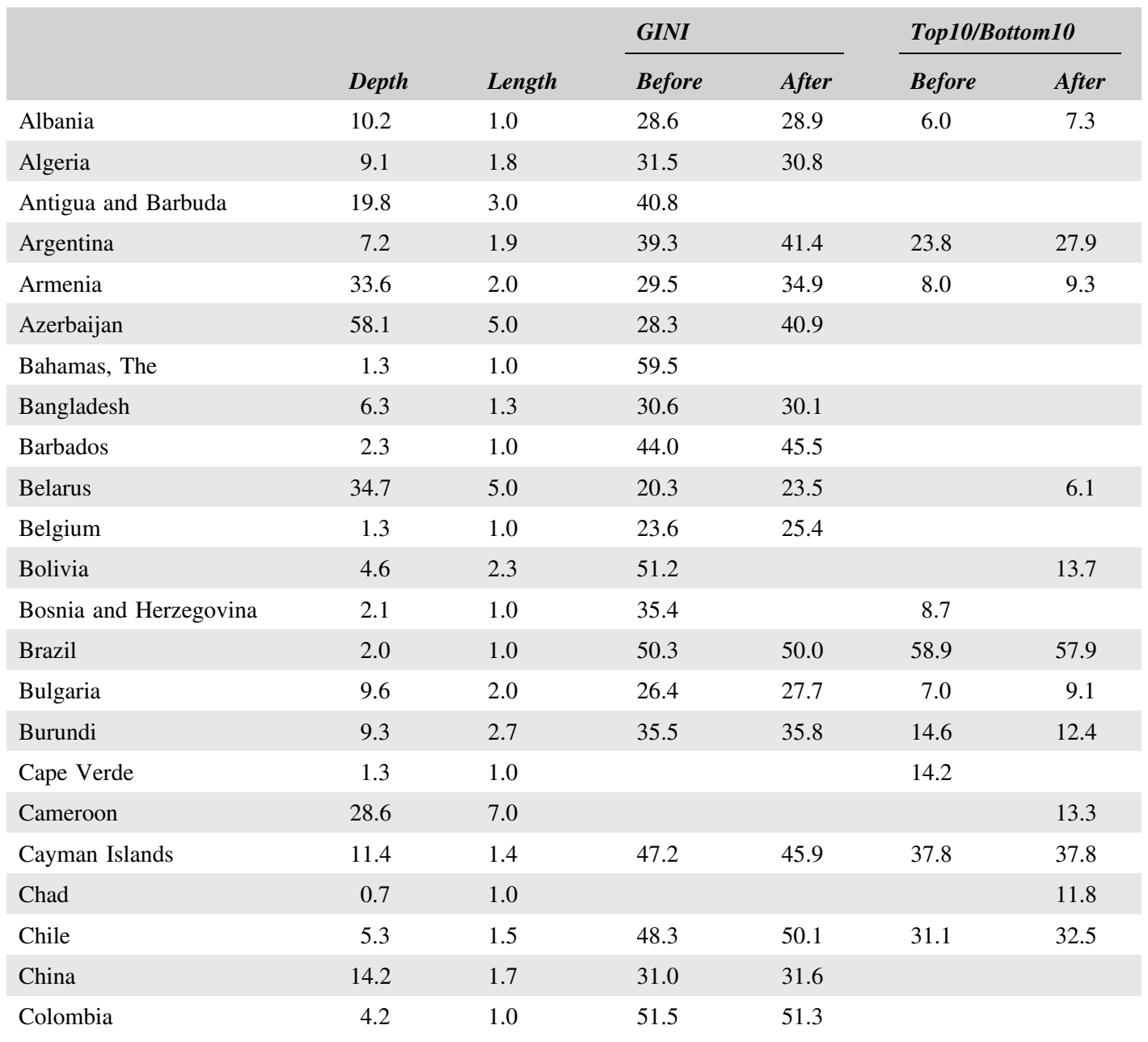




\section{Appendix 1 (Continued)}

\begin{tabular}{|c|c|c|c|c|c|c|}
\hline & & & GINI & & Top10/l & \\
\hline & Depth & Length & Before & After & Before & After \\
\hline Congo, Rep. & 1.6 & 1.0 & 41.9 & & 17.8 & 13.8 \\
\hline Costa Rica & 5.2 & 1.5 & 45.4 & 43.4 & 28.8 & 19.1 \\
\hline Cote d'Ivoire & 1.9 & 1.3 & 40.0 & 39.0 & 12.3 & 12.4 \\
\hline Croatia & 6.7 & 3.5 & 27.6 & 28.3 & 6.8 & 6.8 \\
\hline Cuba & 4.8 & 1.0 & 23.1 & & & \\
\hline Cyprus & 2.0 & 2.0 & 29.8 & 30.4 & & \\
\hline Czech Republic & 4.8 & 1.8 & 23.6 & 24.3 & 5.7 & 5.6 \\
\hline Dominican Republic & 2.6 & 1.0 & 47.7 & 47.3 & 27.6 & 25.7 \\
\hline Ecuador & 1.4 & 1.0 & 51.3 & 44.0 & 40.8 & 42.4 \\
\hline El Salvador & 3.1 & 1.0 & 42.7 & 40.9 & 22.4 & 16.7 \\
\hline Estonia & 9.8 & 1.5 & 33.8 & 34.4 & 9.5 & 10.0 \\
\hline Ethiopia & 6.9 & 1.3 & 32.6 & 28.6 & 9.0 & 8.1 \\
\hline Fiji & 1.8 & 1.0 & 36.2 & 37.3 & 18.0 & 13.2 \\
\hline Gabon & 10.4 & 1.5 & 49.5 & & 13.8 & 13.8 \\
\hline Gambia, The & 3.3 & 1.0 & 46.1 & 49.8 & 23.6 & 18.9 \\
\hline Georgia & 30.1 & 2.7 & 33.6 & 40.9 & 15.3 & 16.9 \\
\hline Ghana & 14.3 & 3.0 & & & & 9.8 \\
\hline Greece & 7.4 & 2.8 & 33.1 & 33.7 & 11.2 & 14.3 \\
\hline Grenada & 2.0 & 1.0 & 48.0 & & & \\
\hline Guatemala & 0.6 & 1.5 & & 51.6 & & 55.7 \\
\hline Guinea & 0.3 & 1.0 & 38.0 & & 11.4 & 8.5 \\
\hline Guinea-Bissau & 14.5 & 1.0 & 39.6 & 36.9 & 18.6 & 9.2 \\
\hline Guyana & 4.5 & 1.6 & 40.5 & 41.0 & & 26.9 \\
\hline Haiti & 1.3 & 2.0 & 53.8 & & & \\
\hline Honduras & 2.2 & 1.2 & 50.9 & 51.5 & 47.9 & 51.2 \\
\hline Hong Kong SAR, China & 4.2 & 1.0 & 45.3 & 47.4 & & \\
\hline Hungary & 3.9 & 1.3 & 27.8 & 29.7 & 6.7 & 6.3 \\
\hline India & 2.8 & 1.3 & 42.2 & 41.4 & & \\
\hline Indonesia & 5.4 & 1.0 & 36.2 & 34.1 & 6.3 & 5.9 \\
\hline Iran, Islamic Rep. & 6.9 & 3.0 & 41.2 & 42.4 & 16.3 & 16.3 \\
\hline Iraq & 6.4 & 1.0 & & & 6.4 & \\
\hline Ireland & 2.4 & 1.5 & 29.7 & 30.4 & 8.1 & 13.2 \\
\hline Israel & 0.1 & 1.0 & 35.1 & 36.1 & 12.5 & 17.3 \\
\hline Jamaica & 7.4 & 4.0 & 39.6 & 47.9 & 13.0 & 21.7 \\
\hline Japan & 2.3 & 1.4 & 28.3 & 28.5 & & \\
\hline Jordan & 15.1 & 2.0 & 34.8 & 38.9 & 9.0 & \\
\hline Kazakhstan & 17.5 & 2.5 & 27.8 & 33.1 & 8.7 & 8.0 \\
\hline Kenya & 4.4 & 1.0 & 57.9 & 54.4 & & \\
\hline
\end{tabular}




\section{Appendix 1 (Continued)}

\begin{tabular}{|c|c|c|c|c|c|c|}
\hline & & & GINI & & Top10/L & 210 \\
\hline & Depth & Length & Before & After & Before & After \\
\hline Korea, Rep. & 3.8 & 1.0 & 30.0 & 31.5 & & \\
\hline Kyrgyz Republic & 10.0 & 1.8 & 33.0 & 37.5 & 7.4 & 8.5 \\
\hline Latvia & 19.3 & 3.0 & 37.4 & 35.7 & 10.6 & 13.8 \\
\hline Lebanon & 1.4 & 1.0 & 40.9 & 40.6 & & \\
\hline Liberia & 36.3 & 2.0 & & & & 12.8 \\
\hline Lithuania & 14.8 & 1.0 & 35.4 & 34.5 & 11.0 & 10.4 \\
\hline Luxembourg & 2.7 & 1.0 & 27.3 & 27.8 & & \\
\hline Macao SAR, China & 3.9 & 2.5 & 29.2 & 36.9 & & \\
\hline Macedonia, FYR & 7.5 & 2.3 & 41.6 & 41.1 & 11.2 & 12.9 \\
\hline Madagascar & 5.8 & 1.0 & & & 14.9 & 14.0 \\
\hline Malawi & 5.7 & 1.0 & 54.1 & 51.9 & 22.4 & 16.9 \\
\hline Malaysia & 3.3 & 1.0 & 41.0 & 41.2 & 17.8 & \\
\hline Maldives & 6.9 & 1.0 & 39.1 & 38.1 & 10.3 & \\
\hline Mali & 1.5 & 1.0 & 35.1 & 39.7 & 7.4 & 20.6 \\
\hline Malta & 1.6 & 1.0 & 28.5 & 27.6 & & \\
\hline Mexico & 3.7 & 1.0 & 46.6 & 46.6 & 24.0 & 26.5 \\
\hline Micronesia, Fed. Sts. & 6.1 & 1.5 & & & 114.9 & 114.9 \\
\hline Moldova & 16.9 & 2.4 & 31.5 & 33.5 & 9.3 & 9.9 \\
\hline Mongolia & 11.8 & 2.5 & 34.6 & 33.9 & 9.3 & 7.8 \\
\hline Montenegro & 4.1 & 1.0 & & & 6.9 & 6.7 \\
\hline Morocco & 2.9 & 1.2 & 40.6 & 37.4 & 10.9 & 11.4 \\
\hline Mozambique & 5.1 & 1.0 & & & & 16.3 \\
\hline Namibia & 1.6 & 1.0 & & 64.2 & & \\
\hline New Zealand & 1.1 & 1.3 & 33.3 & 33.5 & & \\
\hline Nicaragua & 1.6 & 1.0 & 44.0 & 52.0 & 12.1 & 16.6 \\
\hline Niger & 2.6 & 1.3 & 39.8 & 41.3 & 12.6 & 13.1 \\
\hline Nigeria & 9.9 & 2.0 & 41.2 & 42.6 & 15.0 & 20.9 \\
\hline Panama & 14.9 & 2.0 & 48.2 & 49.3 & & \\
\hline Papua New Guinea & 4.5 & 2.0 & 45.7 & 48.7 & 21.5 & 21.5 \\
\hline Paraguay & 3.2 & 2.0 & 48.1 & 47.6 & 42.6 & 34.0 \\
\hline Peru & 9.0 & 1.8 & 54.0 & 52.4 & 12.0 & 25.3 \\
\hline Philippines & 5.1 & 1.3 & 42.6 & 42.0 & 13.0 & 13.3 \\
\hline Poland & 7.0 & 1.0 & 23.0 & 27.1 & & 6.4 \\
\hline Portugal & 3.3 & 1.5 & 33.6 & 34.2 & & \\
\hline Puerto Rico & 7.7 & 4.0 & 36.4 & 26.5 & & \\
\hline Romania & 16.4 & 2.8 & 30.2 & 28.4 & 6.3 & 6.5 \\
\hline Russian Federation & 18.3 & 3.0 & 32.2 & 36.9 & 18.0 & 11.5 \\
\hline Rwanda & 16.9 & 1.8 & 27.4 & 31.5 & & \\
\hline
\end{tabular}




\section{Appendix 1 (Continued)}

\begin{tabular}{|c|c|c|c|c|c|c|}
\hline & & & GINI & & Top10/1 & $n 10$ \\
\hline & Depth & Length & Before & After & Before & After \\
\hline Senegal & 0.4 & 1.0 & 42.3 & 42.6 & 31.5 & 31.5 \\
\hline Serbia & 5.4 & 1.0 & 32.6 & 32.7 & 6.9 & 7.6 \\
\hline Seychelles & 3.9 & 1.8 & 42.8 & 42.2 & 22.9 & 29.8 \\
\hline Sierra Leone & 8.5 & 1.2 & 53.0 & 50.6 & & 10.7 \\
\hline Singapore & 1.3 & 1.0 & 40.4 & 40.5 & & \\
\hline Slovak Republic & 2.7 & 1.0 & 24.9 & 26.5 & 6.4 & 6.6 \\
\hline Slovenia & 5.7 & 1.5 & 24.5 & 25.7 & 5.3 & 5.3 \\
\hline South Africa & 2.5 & 2.0 & 59.3 & 56.7 & 53.8 & 42.1 \\
\hline Sri Lanka & 1.0 & 1.0 & 33.2 & 34.3 & & 11.1 \\
\hline St. Lucia & 2.0 & 1.3 & 46.2 & 44.5 & & \\
\hline St. Vincent \& Grenadines & 3.0 & 1.0 & & 59.4 & & \\
\hline Sudan & 3.9 & 1.5 & 33.9 & 40.1 & 9.8 & \\
\hline Suriname & 0.9 & 2.0 & & 50.4 & & \\
\hline Switzerland & 1.5 & 1.7 & 30.5 & 29.5 & & \\
\hline Syrian Arab Republic & 3.6 & 1.0 & 32.1 & 34.2 & & 8.6 \\
\hline Tajikistan & 32.9 & 4.0 & 26.4 & 31.3 & & 7.1 \\
\hline Thailand & 7.0 & 1.5 & 40.9 & 38.5 & 13.5 & 12.0 \\
\hline Timor-Leste & 5.7 & 1.0 & & & & 6.3 \\
\hline Togo & 3.3 & 3.0 & & & & 12.5 \\
\hline Trinidad and Tobago & 15.5 & 4.5 & 39.8 & 39.9 & 16.7 & 14.4 \\
\hline Tunisia & 0.8 & 1.0 & 39.3 & 381. & 12.5 & 14.3 \\
\hline Turkey & 4.3 & 1.2 & 43.1 & 40.8 & 14.3 & 14.2 \\
\hline Turkmenistan & 14.4 & 1.5 & 27.7 & 32.5 & 6.8 & 10.8 \\
\hline Uganda & 3.6 & 2.0 & & & & 17.5 \\
\hline Ukrain & 38.2 & 5.5 & 24.2 & 28.8 & 5.3 & 5.5 \\
\hline Uruguay & 9.3 & 2.7 & 40.4 & 40.8 & 16.4 & 19.5 \\
\hline Uzbekistan & 23.7 & 5.0 & 24.4 & 35.3 & 4.2 & 30.6 \\
\hline Venezuela, RB & 5.6 & 1.6 & 40.7 & 39.8 & 34.3 & 33.9 \\
\hline West Bank and Gaza & 12.3 & 2.7 & & & 8.7 & 9.4 \\
\hline Zambia & 2.7 & 1.6 & 50.5 & 49.9 & 32.9 & 26.1 \\
\hline Zimbabwe & 12.9 & 2.1 & 48.1 & 50.2 & & \\
\hline LDC Average & 7.9 & 1.8 & 38.0 & 39.0 & 17.5 & 17.8 \\
\hline Australia & 1.3 & 1.0 & 29.2 & 30.0 & 9.4 & 10.4 \\
\hline Austria & 2.1 & 1.0 & 28.4 & 29.5 & 7.1 & \\
\hline Canada & 2.6 & 1.0 & 29.1 & 29.4 & 9.3 & 8.9 \\
\hline Denmark & 1.8 & 1.7 & 25.0 & 23.9 & 6.2 & 5.8 \\
\hline Finland & 6.9 & 2.3 & 24.4 & 24.1 & 5.5 & 5.2 \\
\hline France & 1.5 & 1.0 & 28.4 & 28.6 & 9.5 & $\begin{array}{c}8.1 \\
\text { atinues) }\end{array}$ \\
\hline
\end{tabular}




\section{Appendix 1 (Continued)}

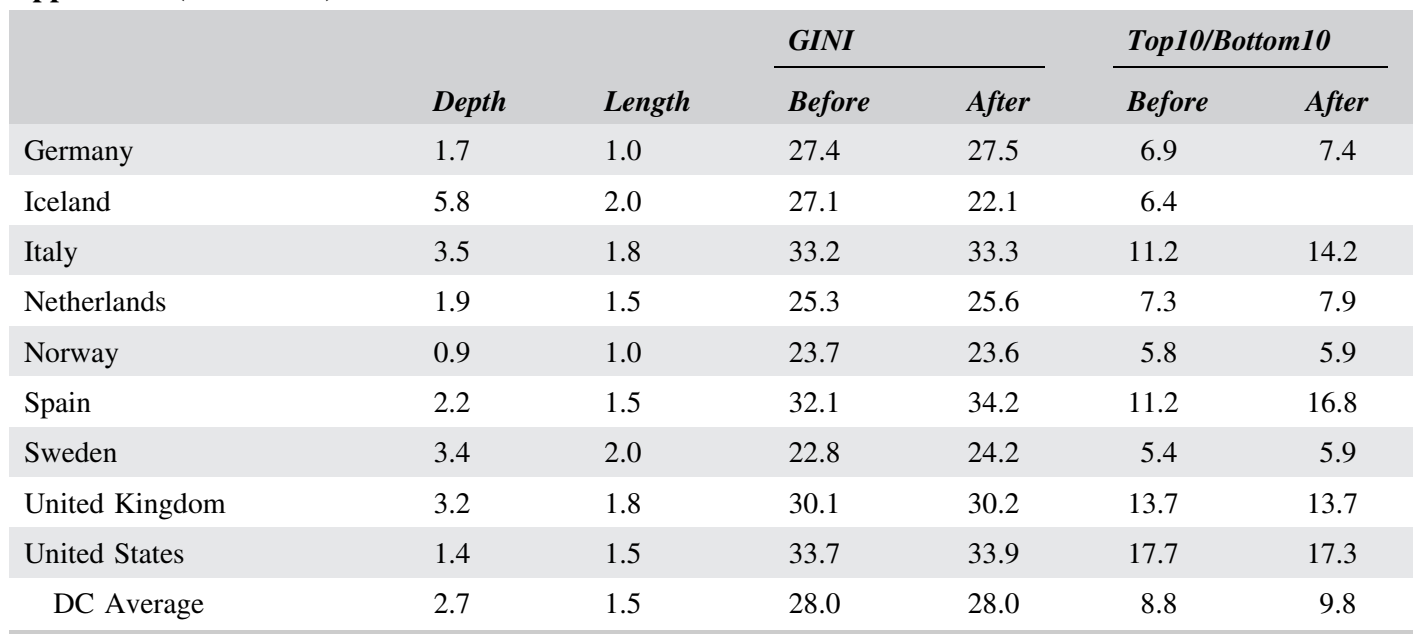




\section{APPENDIX 2}

Recessions around the world, based on The World Development Indicators, The World Bank (Years are shown in the first row, countries, using the World Bank abbreviations, are listed in the left-most column in alphabetical order).

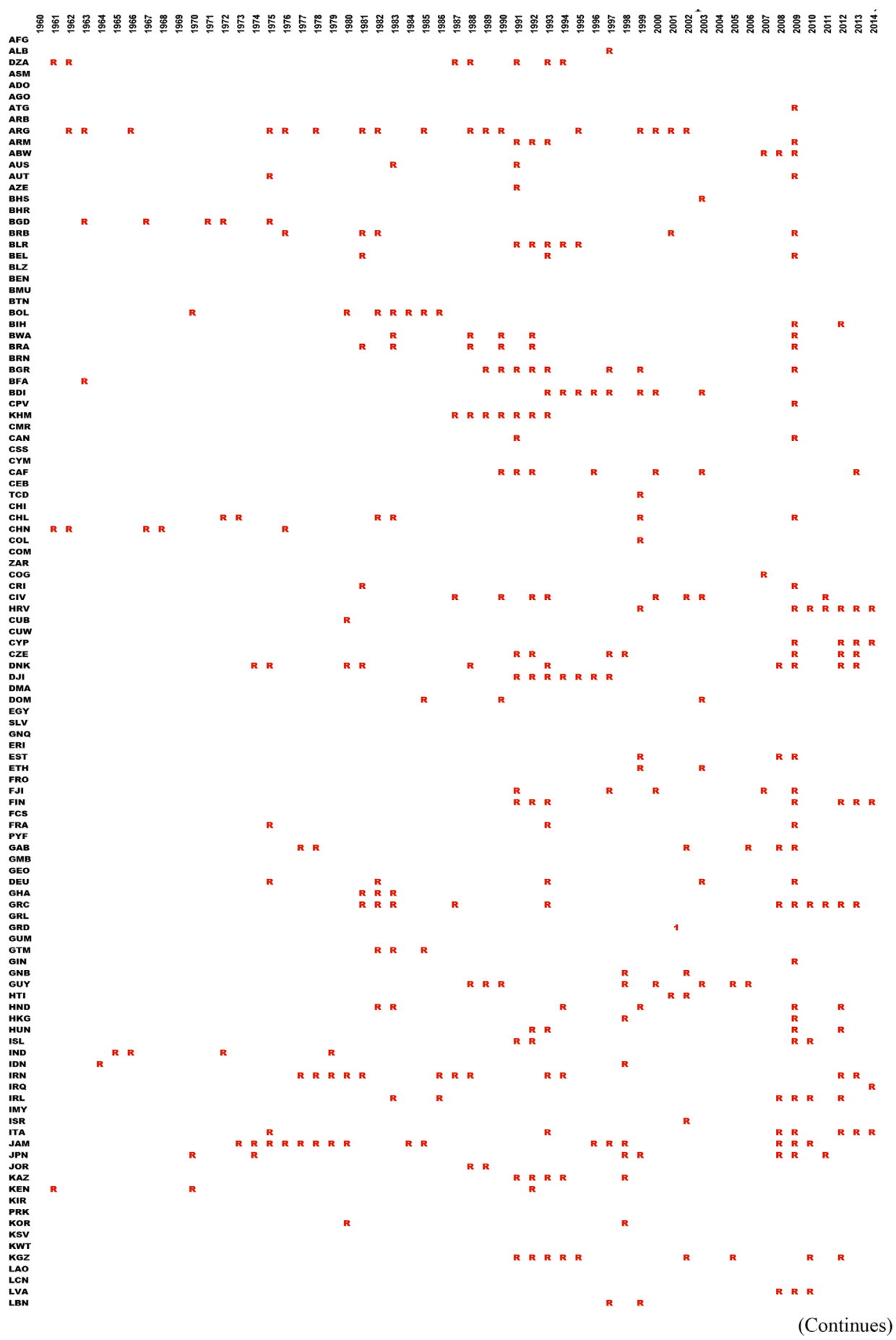


Appendix 2 (Continued)

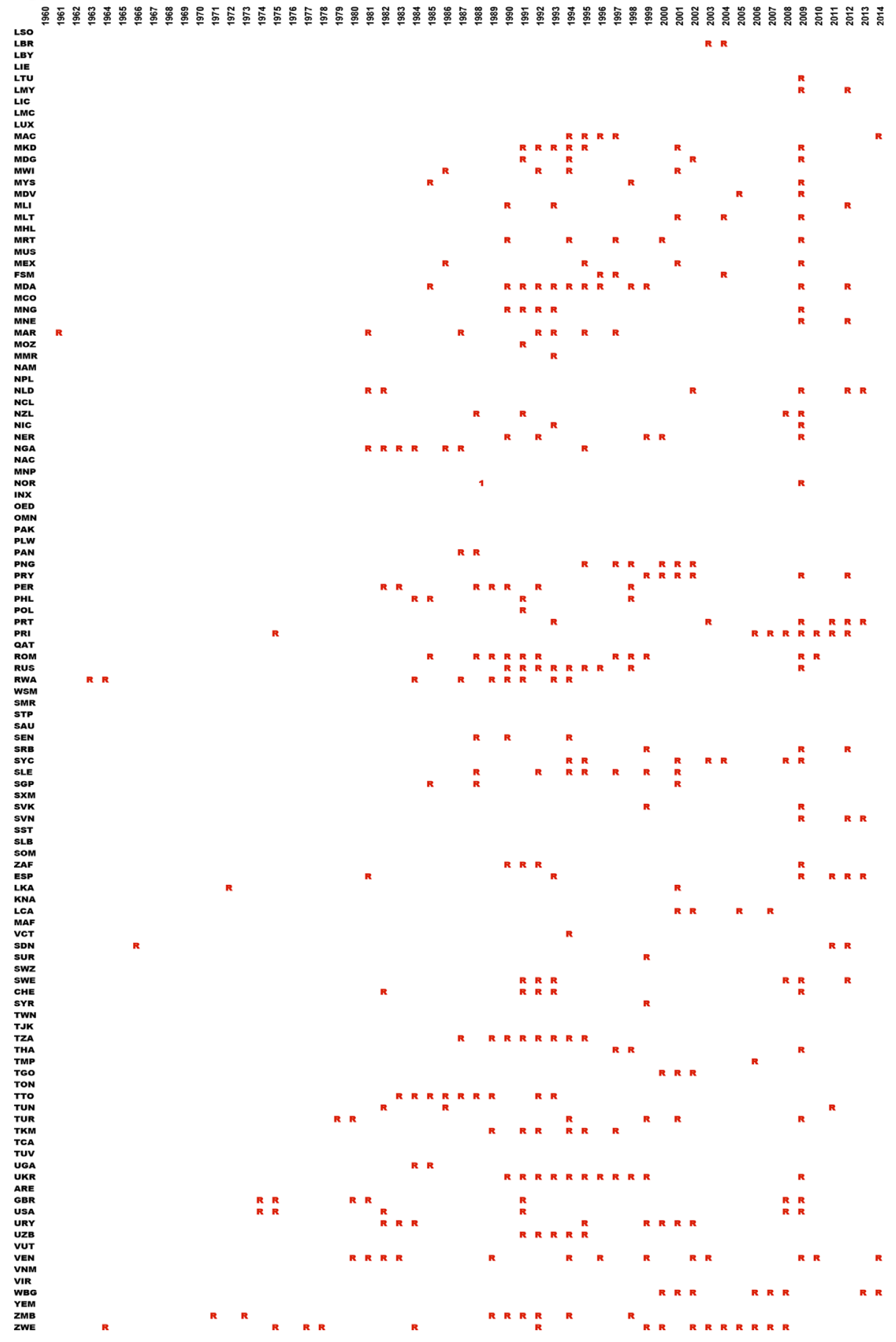




\section{APPENDIX 3}

Average recession severity by country (Author's calculations, source: World Development Indicators, The World Bank).

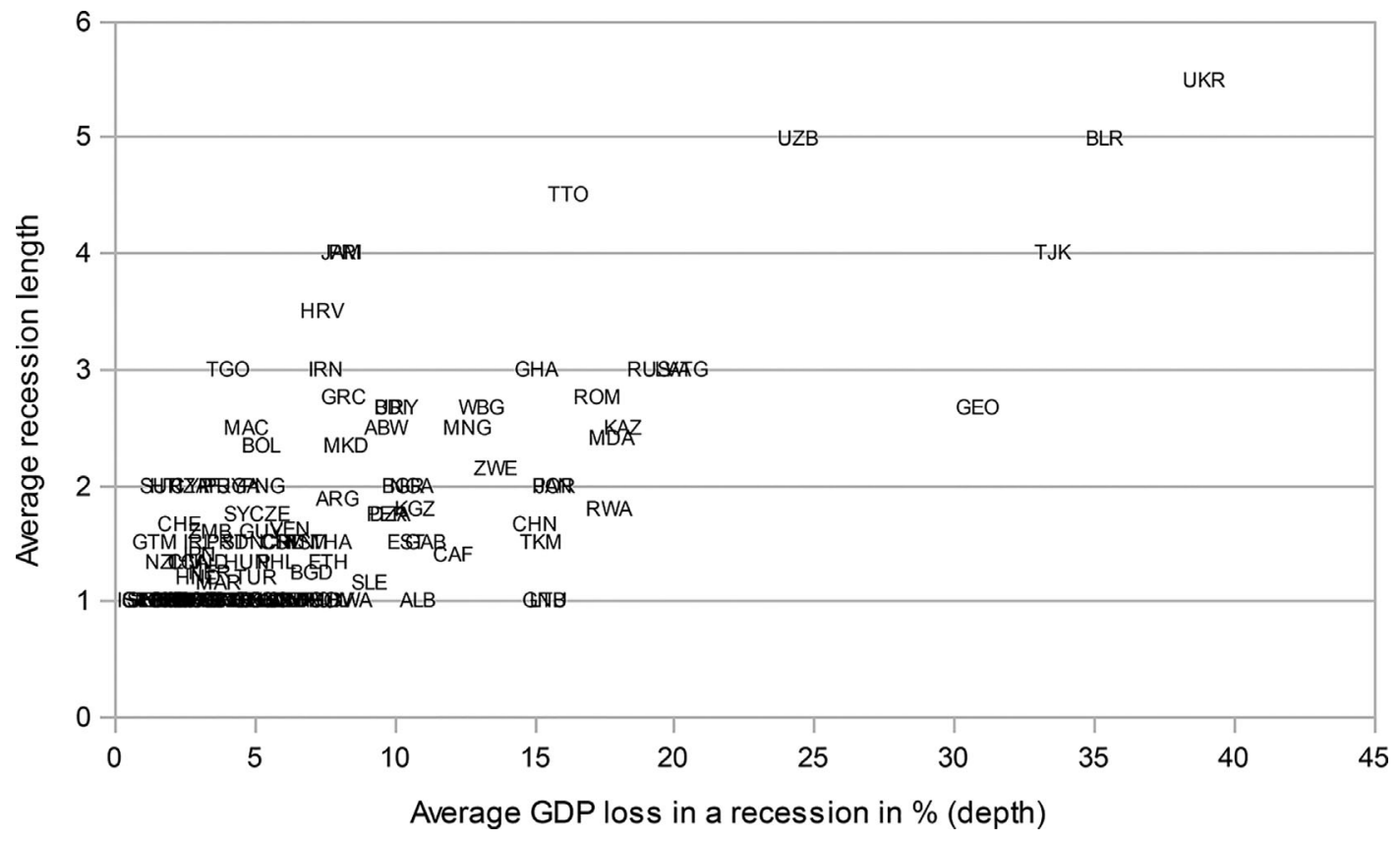

